\title{
Screening glaucium species for drought resistance with emphasis on the contributing physiological characters and overall performance
}

\begin{abstract}
With increasing population demands on the world's water supply, there is a greater need for drastic water conservation methods especially in arid and semiarid regions. Plant species, and cultivars within a species, vary in their salinity/drought tolerance. These variations are the result of variations in genes relating to drought tolerance mechanisms and their interaction with the environment. In order to reduce water usage, it is important to understand the mechanisms of plant adaptation to drought stress. Horned Poppies (Glaucium spp) are members of the Poppy family, Papaveraceae, that are native to the Mediterranean and Middle East regions. The objectives of this study were to
\end{abstract}

Volume 3 Issue 2 - 2019

\author{
Ahmed O Getlawi, Mohamed A Shahba, \\ Harrison G Hughes \\ Department of Horticulture \& Landscape Architecture, USA
}

Correspondence: Mohamed A Shahba, Department of Horticulture \& Landscape Architecture, Fort Collins, Colorado, USA,Email shahbam@lamar.colostate.edu

Received: March 07, 2019 | Published: April 30, 2019

1. Screen for drought tolerance of the common Horned Poppy species available through the Denver Botanic Gardens, G. flavum, G. corniculatum, G. grandiflorum and G. acutidentatums;

2. Examine the effects of drought on plant characteristics as related to their aesthetics as well as the mechanisms associated with drought tolerance such as proline content, total non-structural carbohydrate content (TNC), shoot reducing sugar content (RSC) and evapotranspiration rate $(\mathrm{ET})$ as an indication of water use efficiency among the tested species.

Lysimeter columns were used in this study which was replicated twice. All columns were placed in the Colorado State University plant science green house in Fort Collins, Co. Glaucium spp. were initiated from seeds sown in potting mix, (Pro-Mix, Mycorrhizae and Biofunglcide). Fifty seedlings, at the 3-leaf stage, of each species were transplanted, each per PVS tubes $(15 \mathrm{~cm}$ diameter and $50 \mathrm{~cm}$ long) containing commercial potting mix. The potting mix was mixed with sand 2:1 to increase pore space. Water regimes applied included control (100\% of the total ET), as well as $75 \%, 50 \%$ and $25 \%$ of the total ET. With lower water regimes, leaf color declined over time to unacceptable ratings (below 6) in both G. grandiflorun and G. corniculatum. In G. flavum, and G. acutidentatum, leaf color was not adversely affected under all water regimes. The effect of water stress on leaf color among all species was highly significant. The decline in leaf color was high for all species at $50 \%$ and $25 \%$ of ET. Leaf area decreased linearly in all species with increasing drought with a sharp drop at $25 \%$ of the total ET. G.flavum achieved the highest leaf area at all water regimes followed by G. acutidentatum, G. grandiflorum and G. corniculatum. G. flavum acheived an average leaf area of $24.3 \mathrm{~cm} 2$, while G. acutidentatum leaf area was $22.2 \mathrm{~cm} 2$ at $100 \%$ ET. G. flavum achieved an average height of $45.8 \mathrm{~cm}$ while G. acutidentatum was $40.5 \mathrm{~cm}$ and G. grandiflorum was 30.0 $\mathrm{cm}$ at $200 \%$ ET. G. corniculatum had the lowest height of $27.8 \mathrm{~cm}$ in the control treatment. Increased water stress resulted in fewer flower buds, reduced flower number, and smaller flowers in all tested species. Also, increasing drought decreased the attractiveness of all Glaucium spp. although at different degrees. G. flavum showed greater transpiration efficiency (TE) since it was able to maintain its ET at lower rates while maintaining higher attractiveness when compared with G. acutidentatum, G. grandiflorum and G. corniculatum in order of attractiveness, respectively. In G. flavum, as water regimes decreased from control to 75,50 and $25 \%$ of the total ET, average TNC decreased by $15.1,30.3$ and $48.0 \%$ and the average TNC decrease in G. acutidentatum shoots was $21.6,40.1$, and $53.7 \%$. RSC response to drought treatments followed a different trend than TNC. As water stress increased from control to 75,50 and $25 \%$, average RSC increased by $40.7,101.8$ and $166.5 \%$ in G. flavum and by 17.4 , 40.0 and $103.4 \%$ in G. acutidentatum. The increase was $122.2,39.6$, and $90.6 \%$ in G. grandiflorum and 4.4, 26.5, and $62.5 \%$ in G. corniculatum, respectively. As water regimes decreased from control to 75,50 and $25 \%$, average proline content in shoots increased by 186,325 , and $472 \%$ in $\mathrm{G}$. flavum; 163, 303 and 517\% in G. acutidentatum; 160, 280 and 418\% in G. grandiflorum, and 80, 190, and 340\% in G. corniculatum, respectively. On the basis of the number of times in the best statistical category for leaf characteristics, plant height, flowering characteristics, overall plant quality (attractiveness), water use efficiency, TNC, RSC, and Proline, G. flavum was found to have higher drought tolerance as compared to G. acutidentatum, G. grandiflorum and G. corniculatum. In summary, as drought increased, Glaucium spp. exhibited reduction in leaf characteristics, plant height, flowering characteristics, overall plant quality (attractiveness), TNC, and ET rate, and increased shoot total reducing sugars and proline content. G. flavum showed higher drought tolerance at all water regimes when compared to the other tested species. Since proline accumulation increased with drought stress it is likely that it aided drought tolerance through osmoregulation or by acting as a carbon and nitrogen sink for stress recovery.

Keywords: horned poppies, drought tolerance, proline, glacium flavum, g. corniculatum, g. grandiflorum and g. acutidentatum

Abbreviations: EC, Electrical Conductivity; TNC, Total Nonstructural Carbohydrate Content; RSC, Shoot Reducing Sugar Content; ET, Evapotranspiration Rate; TE, Transpiration Efficiency

\section{Introduction}

The demand for water has increased more than $300 \%$ during the past five decades. With increasing population demands on the world's water supply, there is a greater need for drastic water conservation methods especially in arid and semiarid regions. Because of this immense water usage and diminishing water resources, many arid states have implemented water conservation programs. ${ }^{1}$ The demand for water has led to an inadequate water supply for landscapes and as a result negative impacts on the aesthetics and functionality. Therefore, 
the development of efficient irrigation management programs as well as the selection and improvement of drought tolerant landscape plants has become extremely important to maintain quality landscapes. Plant species, and cultivars within a species, vary in their salinity/drought tolerance. These variations are the result of genes relating to drought tolerance mechanisms and their interaction with the environment. ${ }^{2}$ Usually evaluations for drought and salt tolerance of plants depend on shoot (above ground) growth, as reported in crop yield response curves proposed by Maas and Hoffman. ${ }^{3,4}$

Horned Poppies (Glaucium spp) are members of the Poppy family, Papaveraceae. Glaucium are species that have originated in the Mediterranean and Middle East regions. Some species have a wider distribution than others. Horned poppies require full sun and welldrained soils for optimum growth. They should be spaced between 30 and $60 \mathrm{~cm}$ apart and are best grown by seeding in the fall where they are to bloom and thinning to the desired spacing as they germinate in the spring. For earlier bloom, sow seed indoors 8 to 10 weeks prior to planting and then transplant them into the garden after danger of frost has passed. Germination takes 8 to 15 days at 15 to $18^{\circ} \mathrm{C}$. Seedlings should be transplanted to individual pots when three leaves have formed but before the taproot has developed. Transplanting should be done without disturbing the root system. Stems of horned poppy branch and grow to from a rosette of leaves. The crinkly, gray-green leaves also appear on the stems and below each flower. The goldenyellow flowers may be up to $5 \mathrm{~cm}$ in diameter. There are also orange or red flowers. The roots of the horned poppy are considered poisonous.

All horned poppies have blue-green foliage that is deeply pinnatified to pinnatisect and typically grow $30-50 \mathrm{~cm}$ long. The leaves have varying degrees of texture from glaucous to villous. All leaves are lyrate to sublyrate shaped and have a rosette growth habit. They have solitary blooms on flower stalks that grow above the foliage. All species have four petals in their corolla and their pistil is surrounded by stamens. They all develop long horned-shaped seed siliquiforms with the stigma remaining to cap off the top of the fruit. Species of interest in this study were G. flavum, G. grandiflorum, G. acutidentatum and G. corniculatum.

G. flavum Crantz is the most widely spread species in the genus. It is found from the coasts of Britain and the Atlantic Islands to the coasts of the Mediterranean Basin and the Black Sea. ${ }^{5}$ It grows predominantly on sandy beaches and as a result it is commonly known as the Sea Horned Poppy. This likely indicates that G. flavum is salt tolerant as it grows along the sea. According to Davis, ${ }^{5}$ G. flavum is distinguished from other species by several characteristics. The sepals have crisp, pilose hairs on the surface and the petals can be solid yellow, red or reddish mauve. G. flavum is most often recognized for the yellow petals and is commonly referred to as the Yellow Horned Poppy. The ovary is densely papillose to tuberculate, basically a bumpy surface. The siliquae will retain the papillose to tuberculate texture. In Turkey, G. flavum normally flowers from May through the summer and even though it is most often found at sea level, it does grow into river valleys as well. ${ }^{6}$

G. grandiflorum Boiss \& É. Huet is native to Turkey in the southern part of the Caucasus Mountains but it is also found in Syria, Iran and the Sinai. ${ }^{5}$ Turkey is situated between the Mediterranean Sea and the Black Sea, where the precipitation ranges from 580 to $1300 \mathrm{~mm} /$ year. However, in the mountain ranges of the country there are great differences in climate changes with harsh winters and drier conditions with low precipitation of $400 \mathrm{~mm} /$ year. G. grandiflorum has features that distinguish it from other Glaucium species. It has only one main flower stem while other species have multiple flower stalks growing from the base of the rosette. ${ }^{6}$ The sepals have short, stiff hairs making the surface hirsute. The petals are dark orange to crimson red with a black spot at the base of the petal. The pedicle of the flower exceeds the subtending leaf, which differs from the other Glaucium species. There are two varieties of G. grandiflorum: var. grandiflorum and var. torquatum. G. grandiflorum var. torquatum has red petals with a black blotch and can be found in calcareous hillsides. G. grandiflorum var. grandiflorum is found in fields, banks and rocky slopes.

G. acutidentatum Hausskn \& Bornm is endemic to Turkey where it is found on dry hillslopes and rocky places. ${ }^{5} \mathrm{G}$. acutidentatum is the most glabrous species with smooth sepals and ovaries. Although the ovary is smooth, the resulting siliquae is subtorulose. The petals are solid orange-buff color. G. acutidentatum is found at elevations of 950-1400 m on dry hills. ${ }^{6}$ G. corniculatum (L.) J.H. Rudolph is native to the Mediterranean basin, Atlantic islands, Caucasus Mountains, Bulgaria, Romania, northern Iraq and northwestern Iran., ${ }^{5,6}$. corniculatum also has some unique characteristics. Its leaves have a soft, villous texture and its sepals are scabrous to hirsute. The petals are yellow, orange or red $^{6}$ with a black basal spot. ${ }^{5}$

To reduce water usage, it is important to understand the mechanisms of plant adaptation to drought stress. Drought resistance includes a range of mechanisms employed by plants to withstand periods of drought. ${ }^{7}$ Strategic mechanisms include drought escape, drought avoidance, and drought tolerance. ${ }^{8}$ The significance of each of these strategies is related to drought duration and severity in addition to the plant species. These mechanisms are associated with anatomical, morphological, physiological, and biochemical changes. The reduction in the evapotranspiration (ET) rate and the ability of a species to maintain transpiration as the soil dries are example of drought tolerance mechanisms as the reduction in ET indicates a better water use efficiency. Changes in leaves that facilitate drought tolerance include reduced leaf growth and area, increased pubescence, rolling or folding, and fewer stomates. ${ }^{2}$ The balance between carbohydrate production and consumption will impact the ability of plant species to cope with stresses. ${ }^{9-13}$ Amino acids, especially proline, accumulate in larger amounts to cope with increasing stress in plants. ${ }^{11}$ Proline accumulation is one of the first responses of plants exposed to waterdeficit stress and serves to reduce injury to cells. ${ }^{14}$ Rapid accumulation of proline in tissues of many plant species in response to drought, salt or temperature stresses has been attributed to enzyme stabilization and/or osmoregulation. ${ }^{15,16}$ However, because of contrasting reports related to proline accumulation effect on stress tolerance, ${ }^{17,18}$ its use as selection criterion for stress tolerance has been questioned. ${ }^{19}$ Thus, it is critical that tests be made before making any conclusion regarding the role of proline in stress tolerance of any specific species. ${ }^{20}$

In the previous chapter, it was shown that drought tolerance of Glaucium spp. is dependent on the internal osmoregulator content. There is no published information that addresses the mechanisms of Glaucium spp. drought tolerance. The objectives of this study were to

1) Screen for drought tolerance of the common Horned Poppy species that were available from Denver Botanic Gardens, G. flavum, G. corniculatum, G. grandiflorum and G. acutidentatums; 
2) Examine the effects of drought on plant characteristics associated with aesthetics and the mechanisms associated with drought tolerance such as proline content, total non-structural carbohydrate content (TNC), shoot reducing sugar content (RSC) and ET rates (water use efficiency) among the tested species.

\section{Materials and methods}

Lysimeter columns were used in this study which was replicated twice. All columns were placed in the plant science greenhouse at Colorado State University, Fort Collins, Co. Glaucium spp. were initiated from seeds and transplanted into potting mix, (Pro-Mix, Mycorrhizae and Biofunglcide). Fifty seedlings of each species at the 3-leaf stage were transplanted, 1 per PVS tubes $(15 \mathrm{~cm}$ diameter and $50 \mathrm{~cm}$ long) containing commercial potting mix, (Pro-Mix, Mycorrhizae and Biofunglcide). The potting mix was mixed with sand 2:1 to increase pore space. The plants were maintained in the greenhouse until full establishment and recovery from transplanting. Those seedlings that survived were used as experimental units in the drought study. The experimental design was randomized complete Block (RCB). Each block contained one of the studied species with 16 tubes. Chosen seedlings had the same size and same number of leaves.

Water regimes applied included control $(100 \%$ of the total evapotranspiration), as well as $75 \%, 50 \%$ and $25 \%$ of the total ET. ET was measured weekly. Two representative pots for each of the species were used as lysimeters and were watered with enough water and left to drain for $2 \mathrm{~h}$, after which the weight of each pot was recorded. Each pot was re-weighed every 24 hours. The daily changes in weight represented the daily ET for each species. Treatments were replicated four times. Seedling ET was the average of four lysimeters for each species. Treatments continued until plants reached the flowering stage. ET was updated weekly and treatments were adjusted accordingly. Over the course of the experiments data were collected weekly on plant height, leaf color, leaf area, number of flower buds, size and number of flowers, as well as quality and general attractiveness of the plant using a scale of 0 (not attractive) to 10 (optimum attractiveness). Samples were collected for TNC, RSC, and proline.

ET measurements were collected every 2 to 3 days during the four-month growth period. Five weight readings per pot were made during each measurement and the average value was used for ET calculation. ET was calculated by mass difference and expressed as mmd-1. TNC, RSC, and proline content were determined at the termination of the experiment. Shoot tissue was harvested and washed with cold distilled water to remove plant debris for carbohydrate analysis. Then, approximately $5 \mathrm{~g}$ of samples were freeze-dried (Genesis 25 LL Lyophilizer, Virtis, and Gardiner, NY). After freezedrying, samples were ground with a Wiley mill, sieved thought a screen with $425 \mu \mathrm{m}$ openings, and kept in airtight vials at $-20^{\circ} \mathrm{C}$. Total nonstructural carbohydrate content was measured using the method described by Chatterton et al. ${ }^{19} \mathrm{In}$ brief, $25 \mathrm{mg}$ of freeze-dried samples were transferred to $5 \mathrm{~mL} 0.1 \%$ clarase solution and incubated at $38^{\circ} \mathrm{C}$ for $24 \mathrm{~h}$. Then, $0.5 \mathrm{ml}$ of hydrochloric acid $(50 \%, \mathrm{v} / \mathrm{v})$ was added to the incubation solution. After the solution was incubated at room temperature for $18 \mathrm{~h}$, the $\mathrm{pH}$ value of the solution was adjusted to between 5 and 7 with 10 and $1 \mathrm{~N} \mathrm{NaOH}$. This solution was used to determine TNC content using a spectrophotometer at $515 \mathrm{~nm}$ wavelength (model DU640; Beckman).

To measure the free reducing sugar, $25 \mathrm{mg}$ of the freeze dried, ground, and sieved sample was extracted with $10 \mathrm{ml}$ of $0.1 \mathrm{M}$ phosphate buffer $(\mathrm{pH}=5.4)$ for $24 \mathrm{~h}$ at room temperature. An extracted aliquot $(0.2 \mathrm{~mL})$ was used to determine the reducing sugar content by using the same method as was used to measure TNC.

Actual proline tissue accumulation levels were determined according to the method of Bates et al. ${ }^{21}$ as modified by Torello and Rice ${ }^{18}$ with approximately $0.5 \mathrm{~g}$ fresh weight of tissue. Samples were ground with liquid nitrogen in a mortar. Each sample was homogenized in $10 \mathrm{ml}$ of $3 \%$ aqueous sulfosalicylic acid followed by agitation for $1 \mathrm{~h}$ prior to filtration through \#2 Whatman filter paper. After filtration $2 \mathrm{ml}$ of extract from each sample was reacted with 2 $\mathrm{ml}$ of ninhydrin reagent $(1.25 \mathrm{mg}$ ninhydrin in $30 \mathrm{~mL}$ of glacial acetic acid and $20 \mathrm{~mL}$ of $6 \mathrm{M} \mathrm{H}_{3} \mathrm{PO}_{4}$ ) and $2 \mathrm{ml}$ of glacial acetic acid followed by $1 \mathrm{~h}$ of heating at $100^{\circ} \mathrm{C}$ in an enclosed water bath. Samples were then quickly cooled by immersion in an ice bath and total proline was determined spectrophotometrically at $520 \mathrm{~nm}$. Actual proline tissue accumulation levels were determined by subtracting mean control data from drought treatments data for all cultivars during the entire experimental period.

\section{Data analysis}

The data of the two experiments were subjected to ANOVA to test the experiment effect and the interaction between treatments and experiments. The experimental run was not significant. Therefore, data were pooled over experiments to test the effects of drought, species and their interactions using ANOVA..$^{22}$ Leaf characteristics (color and area), number of flower buds, and flower characteristics (number and size) were analyzed on individual measurement dates to examine drought, and species effects over time. Means were separated by least significant difference at the 0.05 level of probability. Regression analysis was performed to determine the relationship between the measured parameters at the end of the study (dependent variables) and the water regimes (independent variable).

\section{Results and discussion}

\section{Leaf characteristics}

\section{Leaf color}

Comparisons of leaf color among species and water regimes indicated significant differences (Table 1). At all lower water regimes, leaf color declined over time to unacceptable ratings (below 6) in G. grandiflorun and G. corniculatum. In G. flavum, and G. acutidentatum, leaf color was not adversely affected at $75 \%$ regimes (Figure 1 ). The effect of water stress on leaf color among all species was highly significant. The decline in leaf color was high for all species at $50 \%$ and $25 \%$ of irrigation (Figure 1). G. flavum had the highest leaf color level under all treatments. Under the control treatment, there was no difference among G. flavum, G. acutidentatum, and G. grandiflorum in leaf color (full rating of 10). They showed $100 \%$ full green leaf while G. corniculatum showed a rating of 9.5. Leaf color decreased as water regimes decreased. At the water regime of $75 \%$ of the total ET, G. flavum and G. acutidentatum did equally well and leaf color rating did not change (rating of 10). G. grandiflorum had a reduced rating of (9) while G. corniculatum rating was 8.6 at $75 \%$ ET (Figure 1). Under the lowest water regime ( $25 \%$ of the total ET), the leaf color of all species was adversely affected, however, only G. grandiflorum and $\mathrm{G}$. corniculatum leaf color ratings were below the accepted levels (4.8 and 4.5 respectively) (Figure 1). Similarity, leaf greenness decreased under severe water stress in all almond genotypes studied 
by Yadollahia et al. Flexas and Medrano ${ }^{23,24}$ reported a reduction in leaf greenness in $\mathrm{C} 3$ plant leaves under water stress and associated that to degradation in chlorophyll content. The retention of leaves or the observation of 'stay green' under water stress conditions has been reported in cassava lines MH96/0686 and has correlated well with drought tolerance and improved yields in cassava. ${ }^{25}$ The decrease in relative greenness of the leaf under water stress treatment as compared to the well- watered treatment is likely due to a decrease in chlorophyll content as reported in rapeseed plants. ${ }^{26}$ There was a $38 \%$ reduction in chlorophyll content when compared to full irrigation of plants. ${ }^{27}$ Increasing water stress reduced the (Chl a) and the (Chl a:b) significantly. ${ }^{28}$ The pigment content generally decreased due to low synthesis rate and rapid degradation under water stress. ${ }^{23,29,30}$

Table I Analysis of variances with mean square and treatment significance of leaf color, leaf area, plant height, number of flower buds, number of flowers, flower area, plant quality (attractiveness), total non-structure carbohydrate content (TNC), shoot reducing sugar content (RSC), proline content and total evapotranspiration in Glaucium spp

\begin{tabular}{|c|c|c|c|}
\hline \multirow[b]{2}{*}{ Parameters } & \multicolumn{3}{|l|}{ Source } \\
\hline & $\begin{array}{l}\text { Species } \\
\text { (S) }\end{array}$ & $\begin{array}{l}\text { Water regimes } \\
\text { (W) }\end{array}$ & sXW \\
\hline Leaf color (0-10 scale) & $8.5^{* *}$ & $65.1 * *$ & $59.2^{*}$ \\
\hline Leaf area $(\mathrm{cm} 2)$ & $3.5^{* *}$ & $4.11 * *$ & $3.2^{*}$ \\
\hline Plant height (cm) & $2.22 * *$ & $2.66 * *$ & $2.33 *$ \\
\hline Number of buds & $29.5 * *$ & $67.0 * *$ & $20.6 *$ \\
\hline Number of flowers & $3.2^{* *}$ & $6.1 * *$ & $4.9 *$ \\
\hline Flower area $(\mathrm{cm} 2)$ & $8.8^{* *}$ & $9.7 * *$ & $1.7^{*}$ \\
\hline $\begin{array}{l}\text { Plant quality (0-10 } \\
\text { scale) }\end{array}$ & $8.5^{* *}$ & $9.6 * *$ & $6.9 *$ \\
\hline TNC (mgg-I dry wt) & $8800 * *$ & $711.0 * *$ & $895.0 *$ \\
\hline RSC (mgg-I dry wt) & $56.0 * *$ & $92.0 * *$ & $21.0 *$ \\
\hline $\begin{array}{l}\text { Proline content ( } \mu \mathrm{g} g-\mathrm{I} \\
\text { fresh wt.) }\end{array}$ & $1270 * *$ & $1337 * *$ & $1227^{*}$ \\
\hline Total ET (mm d- I) & $1.9 .0 * *$ & $5.1 * *$ & $2.9 *$ \\
\hline
\end{tabular}

*Significant at $\mathrm{P} \leq 0.05$.

** Significant at $\mathrm{P} \leq 0.01$.

\section{Leaf area}

Analysis of variance indicated significant differences among species and among water regimes and their interactions (Table 1). Linear regression indicated a significant negative association between leaf area and water regimes (Table 2). Leaf area decreased linearly in all species with increasing drought with a sharp drop at the water regime of $25 \%$ of the total evapotranspiration. G. flavum achieved the highest leaf area at all water regimes followed by G. acutidentatum, G. grandiflorum and G. corniculatum. G. flavum acheived an average leaf area of $24.3 \mathrm{~cm}^{2}$, while G. acutidentatum achieved leaf area of 22.2 $\mathrm{cm}^{2}$ at $100 \%$ ET. G. grandiflorum was ranked third with an average leaf area of $22.0 \mathrm{~cm}^{2}$ while G. corniculatum had the lowest leaf area of $19.9 \mathrm{~cm}^{2}$ with control treatment (Figure 2). Leaf area decreased from 23 to $21.8,18.1$ and $12.5 \mathrm{~cm}^{2}$ in G. flavum; from 22.2 to $18.2,12.5$, and $10.2 \mathrm{~cm}^{2}$ in $\mathrm{G}$. acutidentatum, from 22.0 to17.7, 10.6, and $7.8 \mathrm{~cm}^{2}$ in G. grandiflorum, and from 19.9 to $15.4,10.3$, and $7.0 \mathrm{~cm}^{2}$ in G. corniculatum with increased drought from the control to 75,50 and $25 \%$ ET, respectively (Figure 2). It is logic that the leaf area followed the trend of leaf color since healthy leaves should have a greater leaf area. Although there was considerable decrease in overall leaf area in G. flavum, it appeared to be the most drought tolerant species. Water stress is one of the most common environmental factors affecting plant growth and productivity. Reduced water availability induces numerous physiological and biochemical changes in all plant organs.

Gas exchange in leaves is limited, which in turn reduces carbon assimilation. Changes in the distribution of photo- assimilates can reduce vegetative growth ${ }^{31-33}$ as well. The reduction of leaf area is principally explained by a lower leaf unfolding rate which results in smaller leaf size. ${ }^{34,35}$ The reduction in leaf area could be an adapting mechanism to water stress. Water stress induced a significant reduction in the leaf area which is a benefit in reducing leaf transpiration. ${ }^{36}$ Similar results were found by Grant ${ }^{37}$ who studied ten strawberry cultivars under different water regimes. Furthermore, it was concluded that strawberry genotypes differed in their response to water deficiency although drought stress reduced leaf area in all of them. ${ }^{38}$ In another study, it was found that total leaf area and leaf blade area decreased with the increase in water stress in Campylotropis polyantha seedlings, while total leaf area was reduced sharply in response to progressive water stress. ${ }^{28}$ Similar results were found in eggplants, ${ }^{39}$ different almond genotypes and wheat cultivars. ${ }^{40,41}$ The common cause of the reduced vegetative growth of vegetables under water deficit conditions has been understood to be accelerated leaf senescence in eggplant. ${ }^{42}$

However, the leaf area in bell pepper was not affected by drought. ${ }^{43}$ Specific leaf area (SLA), an indicator of leaf thickness, has often been observed to be reduced under drought conditions. ${ }^{44}$ Decrease in SLA in plants under drought stress may be due to the different sensitivity of photosynthesis and leaf area expansion to soil drying. Drought stress affects leaf expansion earlier than photosynthesis. ${ }^{45,46}$ Reduction of SLA is assumed to be a way to improve water use efficiency (WUE) ${ }^{47-49}$ This is because thicker leaves usually have a higher density of chlorophyll and proteins per unit leaf area and, hence, have a greater photosynthetic capacity than thinner leaves. The mechanism, by which plant leaf area is reduced under water stress, is thought to be the reduction of cell elongation, which leads to reduction of cell size and therefore a reduction of leaf area. ${ }^{50}$

\section{Plant height}

Generally, there was a significant decrease in plant height as drought stress increased. (Table 1). G. flavum achieved an average height of $45.8 \mathrm{~cm}$ while G. acutidentatum averaged $40.5 \mathrm{~cm}$; G. grandiflorum averaged $30.0 \mathrm{~cm}$, and G. corniculatum the lowest at $27.8 \mathrm{~cm}$ in the control treatment (Figure 3). Plant height decreased from 45.8 to $42.0,30.0$ and 21.3 in G. flavum, from 40.5 to 33.0, 22.5 , and $14.3 \mathrm{~cm}$ in G. acutidentatum, from 30.0 to 24.0, 13.0, and $5.3 \mathrm{~cm}$ in G. grandiflorum, and from 27.8 to $20.3,9.0$, and 4.5 $\mathrm{cm}$ in $\mathrm{G}$. corniculatum as the drought increased from the control to 75,50 and $25 \%$ of the total ET, respectively (Figure 3). Several reports have reported similar negative effects of drought on plant height. ${ }^{43,51-55}$ Previous studies indicated a significant reduction in plant height in mungbean (Vigna radiate L.), ${ }^{55}$ in Satureja hortensis, ${ }^{51}$ and in Eragrostis curvula. ${ }^{52}$ However, Alexieva ${ }^{43}$ reported no effect on 
pea and wheat height due to drought stress. The reduction in growth parameters such as height could be attributed to several effects such as the osmotic stress and/or ionic toxicity ${ }^{56}$ which is more harmful to plants during the succulent seedling stage in addition to the stressful effects of ion uptake. ${ }^{57,58}$ Drought stress favors the growth of roots as an adaptive mechanism rather than shoots which results in a decrease in plant height. Marcum ${ }^{59}$ reported root mass increased under stress conditions of several grasses. Also, root growth stimulation under stress conditions has been reported in stress tolerant grasses by others as well. ${ }^{60,61}$ Shahba. ${ }^{12}$ Shahba et al. ${ }^{13}$ Shahba et al. ${ }^{55}$ reported an increase in root mass of Bermuda grass cultivars and seashore paspalum cultivars under salinity and drought condition. The reduction in plant height might be due to inhibition of cell division or cell enlargement with less soil moisture availability. ${ }^{55,62}$ Rozema and Visser ${ }^{63}$ indicated that increased rooting and the associated increase in root absorbing area is an adaptive mechanism to the osmotic and nutrient deficiency stresses occurring under stress conditions which in turn results in a reduction in shoot system and plant height. Unfortunately, we were not able to measure the change in root mass in this study to support this argument in Glaucium spp.

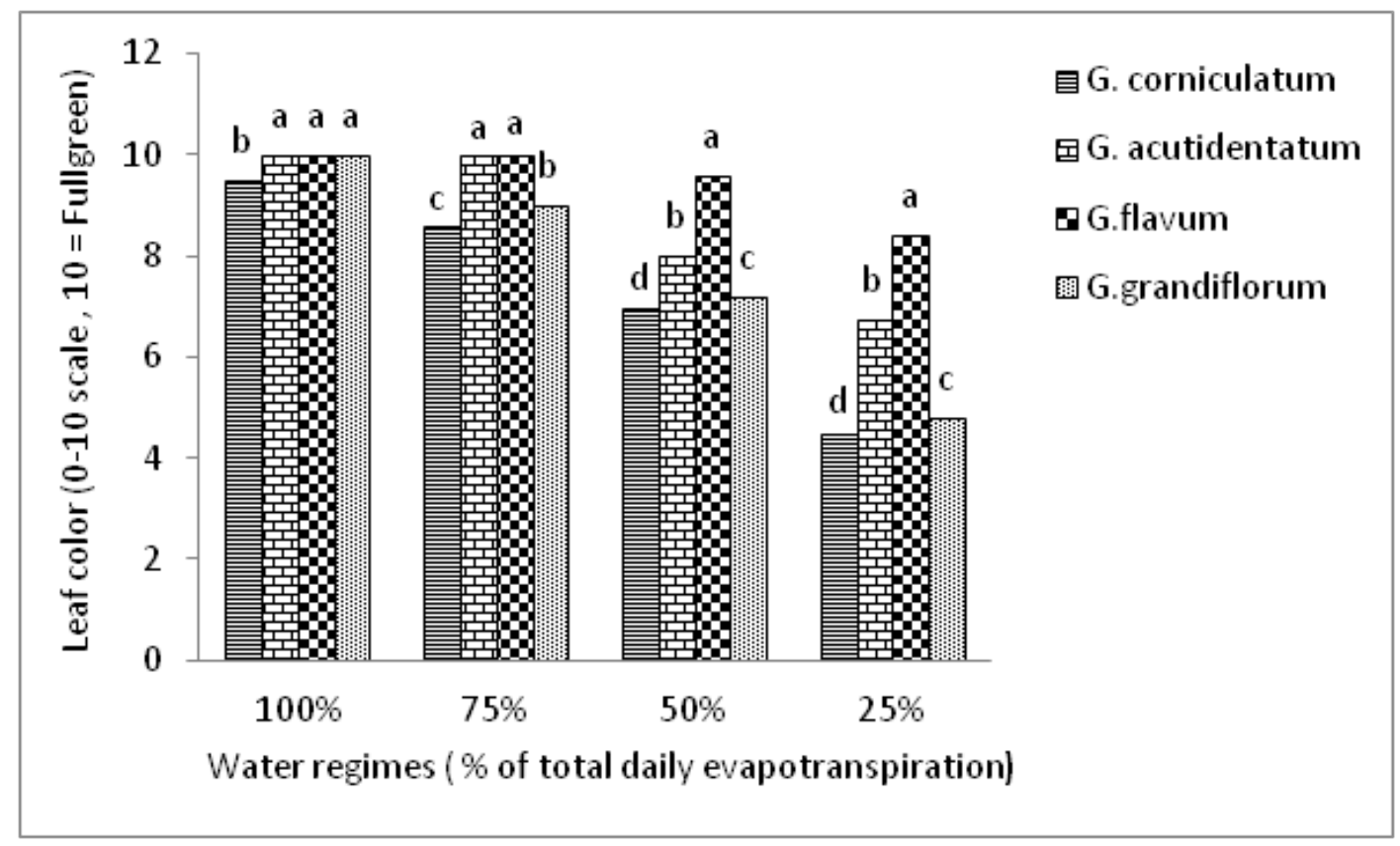

Figure 1 Effect of four different water regimes on leaf color of four Glaucium spp. Columns labeled with different letters are significantly different at $\mathrm{P}=0.05$ within each water regime.

Table 2 Linear regression of different parameters of Glaucium spp. measured at the end of the experiment vs. water regimes of control (C), 75,50 , and $25 \%$ of the total evapotranspiration

\begin{tabular}{|c|c|c|c|c|c|c|}
\hline \multirow{3}{*}{ Species } & \multicolumn{6}{|l|}{ Parameter } \\
\hline & \multicolumn{2}{|c|}{ Plant quality (0-10 scale) } & \multicolumn{2}{|l|}{ Leaf area $\left(\mathrm{cm}^{2}\right)$} & \multicolumn{2}{|c|}{ Flower area $\left(\mathrm{cm}^{2}\right)$} \\
\hline & Regression & $\mathbf{R}^{2}$ & Regression & $\mathbf{R}^{2}$ & Regression & $\mathbf{R}^{2}$ \\
\hline G. acutidentatum & $Y=4.2-0.2 X$ & $0.80 * *$ & $Y=102.5-2.2 X$ & $0.82 * *$ & $Y=210.5-6.3 X$ & $0.80 * *$ \\
\hline G. corniculatum & $Y=6.6-0.3 X$ & $0.7 I^{*}$ & $Y=\mid 25.2-2.1 X$ & $0.69 *$ & $Y=202.6-8.2 X$ & $0.65 *$ \\
\hline G. flavum & $Y=7.8-0.5 X$ & $0.82 * *$ & $Y=116.8-2.3 X$ & $0.85^{* *}$ & $Y=113.3-8.8 X$ & $0.90 * *$ \\
\hline G. grandiflorum & $Y=3.9-0.3 X$ & $0.65^{*}$ & $Y=121.2-2.5 \mathrm{X}$ & $0.65^{*}$ & $Y=199.0-6.8 X$ & $0.67^{*}$ \\
\hline
\end{tabular}

*Significant at $\mathrm{P} \leq 0.05$.

**Significant at $\mathrm{P} \leq 0.01$ 


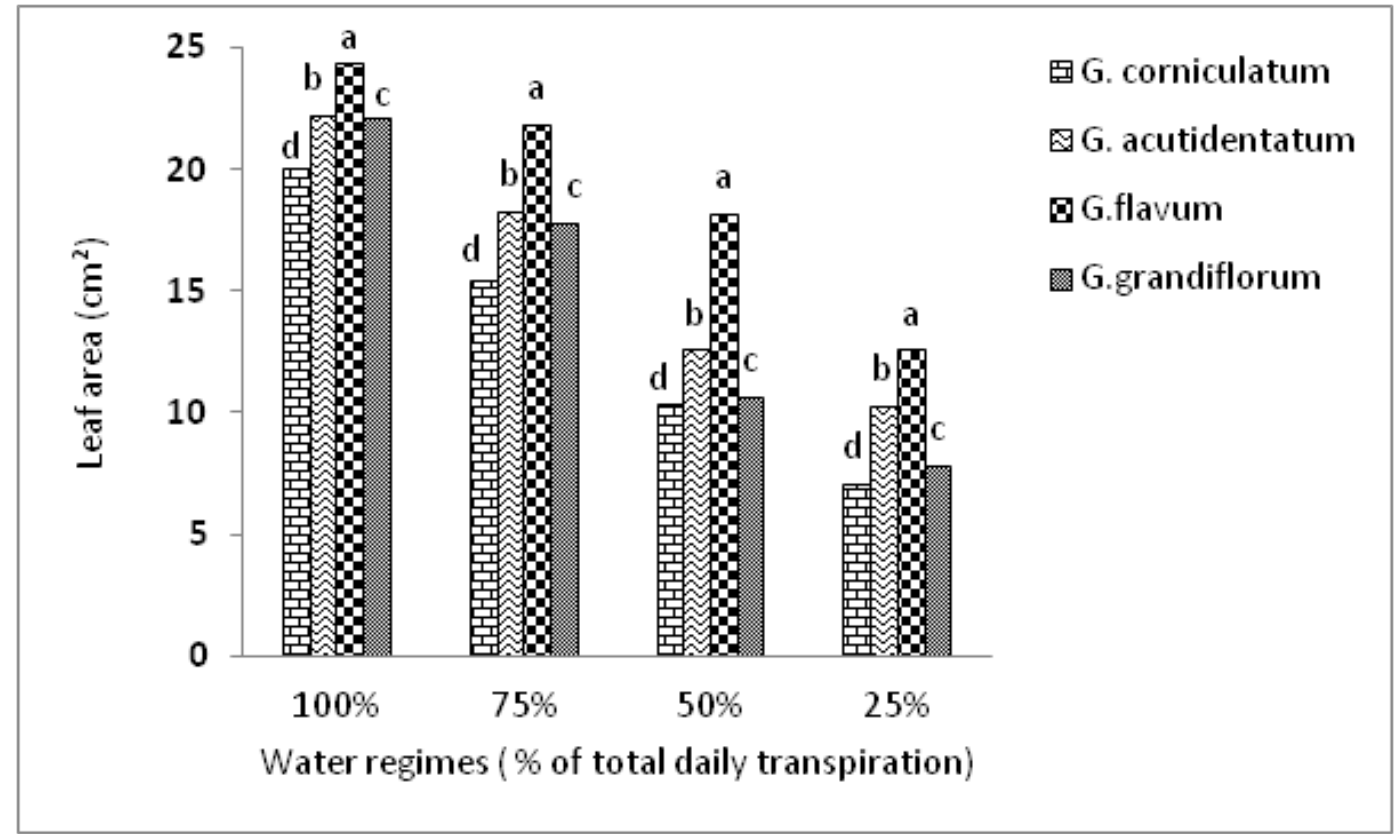

Figure 2 Effect of four different water regimes on leaf area of four Glaucium spp. Columns labeled with different letters are significantly different at $\mathrm{P}=0.05$ within each water regime.

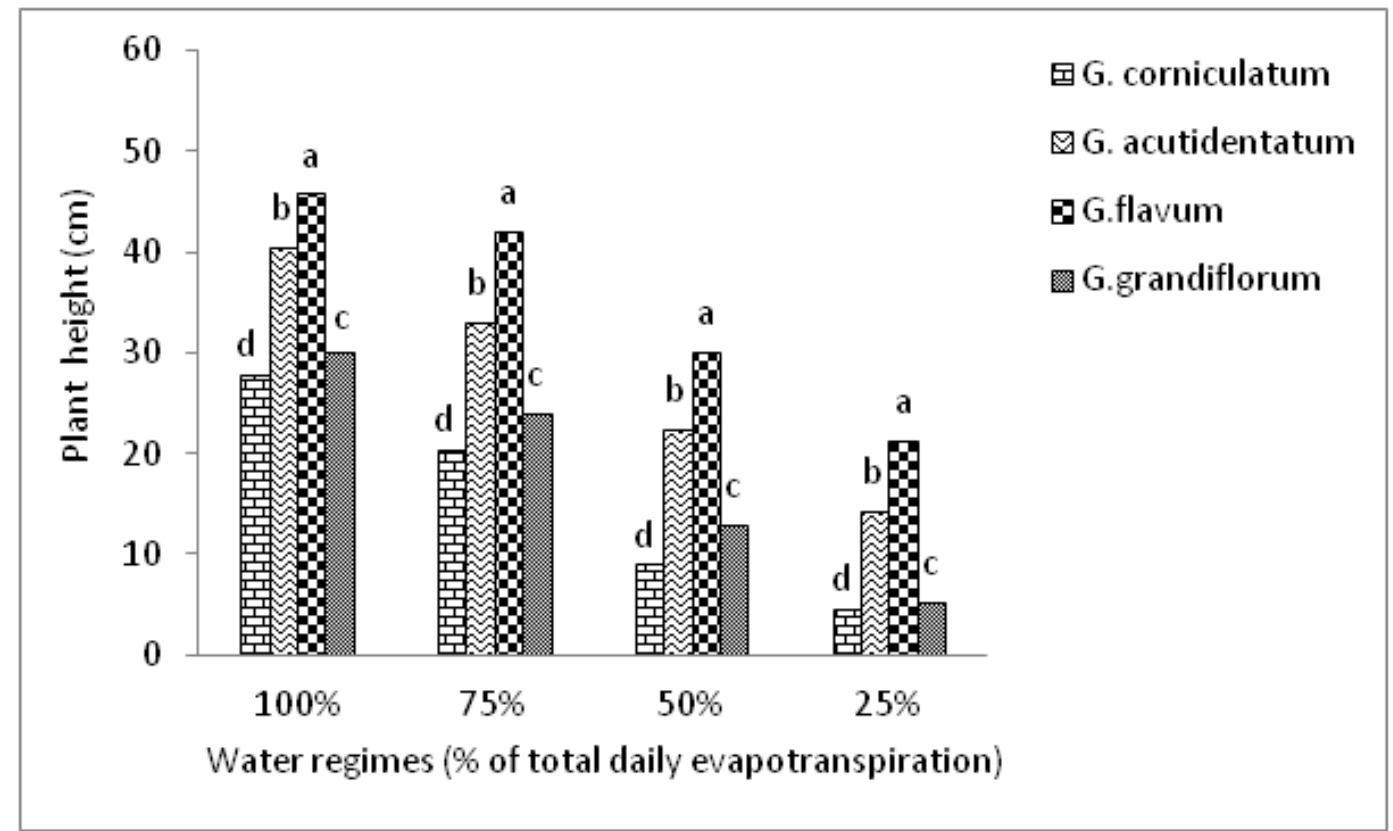

Figure 3 Effect of four different water regimes on plant height of four Glaucium spp. Columns labeled with different letters are significantly different at $\mathrm{P}=0.05$ within each water regime.

\section{Flowering characteristics}

Number of flower buds. Numbers of flower buds are varied significantly among Glaucium spp., water regimes and their interaction (Table 1). Increased water stress resulted in fewer flower buds (Figure 4). In G. flavum, as water regimes decreased from control to 75,50 and $25 \%$ ET, average bud number decreased by $7.8,37.5$ and $54.7 \%$ respectively. The decrease was similar in G. acutidentatum where the average number of flower buds decreased by 11,33 and $55.6 \%$ when drought increased from control to 75,50 and $25 \%$, respectively. G. grandiflorum and G. corniculatum did not produce any flower buds at an ET of $25 \%$. This study demonstrated that drought significantly affected the production of flower buds. At the control treatment, all species produced flower buds with the highest number produced by G. flavum (32.0), followed by G. acutidentatum (22.5), G.grandiflorum (9.9) and the lowest number by G. corniculatum (8.5) (Figure 4).

Number of flowers. Flower number is another indicator of plant 
vigor. Number of flowers varied significantly $(\mathrm{P}<0.05)$ among species, water regimes and their interaction (Table 1). The number of flowers declined with increased drought levels. The decline in flower number under higher drought stress was more severe and more rapid in the two less drought tolerant species (G. grandiflorum and G. corniculatum) while more moderate in G. flavum and G. acutidentatum (Figure 5). G. flavum had higher flower number under all water regimes when compared to other species (Figure 5). G. corniculatum had the lowest number of flowers at all water regimes. At the control treatment, the highest number of flowers produced was by G. flavum (26.5) followed by acutidentatum (20.5), G. grandiflorum (10) and G. corniculatum (8). Only G. flavum and G. acutidentatum produced flowers at the water regime of $25 \%$ of ET (Figure 5).
Flower area. Comparisons of flower area among species and among water regimes and their interaction clearly showed significant differences (Table 1). Flower area decreased linearly with increasing drought. Regressions were strongly linear, with slope more negative with less tolerant species (Table 2). As water regime decreased, the flower area decreased. At the control treatment, flower area was the greatest in G. flavum $\left(22.4 \mathrm{~cm}^{2}\right)$ followed by $\mathrm{G}$. acutidentatum $\left(19.3 \mathrm{~cm}^{2}\right)$, G. grandiflorum $\left(10.5 \mathrm{~cm}^{2}\right)$, and G. corniculatum had the smallest flower area $\left(9.5 \mathrm{~cm}^{2}\right)$ (Figure 6). The decline in flower area under substantial drought stress was more severe and more rapid in the less drought tolerant species (G. grandiflorum and G. corniculatum) while more moderate in G. flavum and G. acutidentatum (Figure 6). G. flavum had the greatest flower area under all water regimes compared to other species (Figure 6).

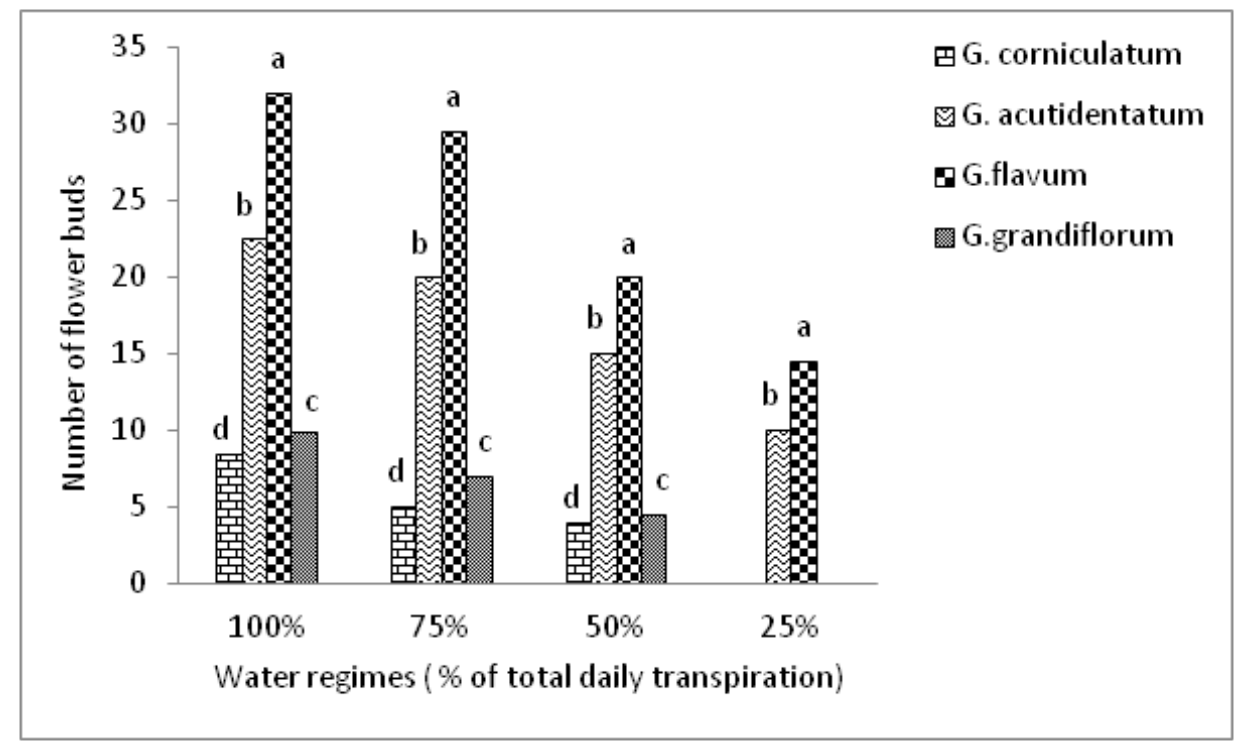

Figure 4 Effect of four different water regimes on number of flower buds of four Glaucium spp. Columns labeled with different letters are significantly different at $\mathrm{P}=0.05$ within each water regime.

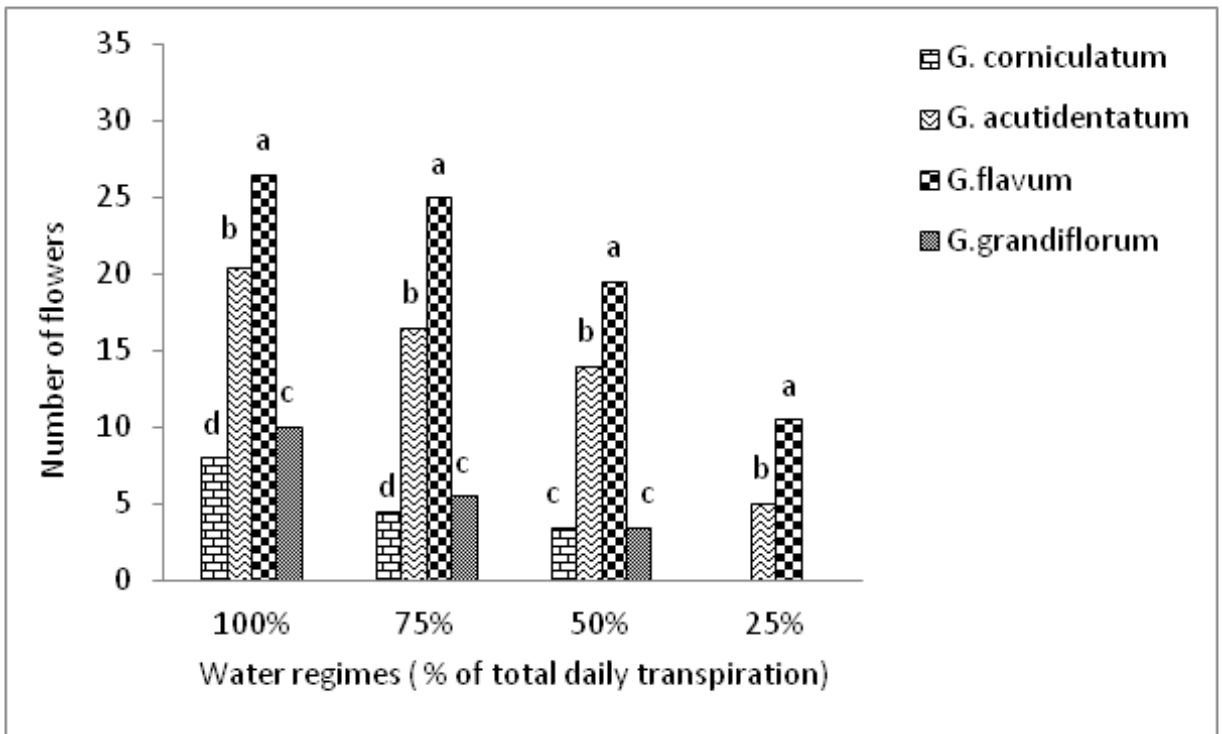

Figure 5 Effect of four different water regimes on number of number of flowers of four Glaucium spp. Columns labeled with different letters are significantly different at $\mathrm{P}=0.05$ within each water regime. 
Previous reports have indicated similar results in other species. Water stress affected flower induction in rice (Oryza sativa L.) ${ }^{64}$ and in satsuma mandarin Citrus unshiu Marc. ${ }^{65,66}$ Fewer flowers were often observed in cultivated satsuma mandarin under drought conditions. ${ }^{67}$ Oilseed rape was also significantly affected by water shortage during the most sensitive flowering stage. ${ }^{68}$ Koshita and Takahara ${ }^{65}$ reported negative effects on flower-bud formation in citrus because of drought as well. Southwick and Davenport ${ }^{66}$ indicated that both continuous and cyclical water-stress treatments reduced flowering of Citrus latifolia Tan. However, cotton flower buds have been shown to be relatively insensitive to water deficits. ${ }^{69}$ Flower bud induction under water stress treatments is likely due to the influence on hormonal metabolism roles. For example, plant growth regulators have been applied exogenously to elucidate the roles of plant hormones in flower-bud induction of citrus. The conclusion was that exogenously applied GA reduces the number of flowers in the following spring. ${ }^{70}$ The suppression of plant growth under drought conditions may be due to decreased availability of water that leads to the toxicity of sodium chloride. ${ }^{71}$ Also, the hydrolysis of reserved foods to produce energy necessary for biological functions and survival reduces the amount of resources available for flower formation. Drought stress imposes additional energy requirements on plant cells and less carbon is available for growth and flower primordial initiation. ${ }^{54,72,73}$ Drought effect on flower formation can be an indirect result of its effect on photosynthesis (Pn) efficiency. Pn is less sensitive to drought as compared to other growth parameters, ${ }^{74}$ but photosynthetic capacity can be reduced in the presence of great drought levels due to stomata closure, damage to photosynthetic systems by excessive energy, structural disorganization or reduction in photochemical quenching. ${ }^{75,76}$ On the other hand, Razmjoo et al. ${ }^{54}$ related the negative effects of drought on flower number to its early effect on the growth and production of a strong shoot system. Pessarakli and Touchane $\mathrm{e}^{77}$ found that the reduction in biomass production due to drought stress is more obvious than the reduction in shoot lengths in bermudagrass. The decrease in plant biomass production due to drought may be attributed to low or medium water potential, specific ion toxicity, or ion imbalance that resulted from insufficient water for osmotic balance. ${ }^{56}$ In addition, elevated drought may adversely affect photosynthesis and as a result adversely affect plant biomass production through reduced accumulation of carbon products. ${ }^{78}$ The reduction in the number of flowers usually is more drastic than other growth parameters under high drought as it is a cumulative effect. ${ }^{54}$

Three contrasting faba bean genotypes (Vicia faba L.) were tested under drought stress. A reduction in the number of flowers was recorded. Saxena et al. ${ }^{79}$ concluded that the reduced flowering was a mean for maintaining stable and high seed yields under water stress. Also, reproductive development at the time of flowering is especially sensitive to drought stress. ${ }^{80-82}$ Drought stress interferes not only with flowering but also flower opening, nectar production, and turgor maintenance of floral organs as well. ${ }^{83}$ Water stress during flower induction and inflorescence development may lead to a delay in flowering (anthesis) or even complete inhibition of flowers. ${ }^{84,85}$ This confirms the differences in sensitivity to drought among different species and/or cultivars ${ }^{12,13,55,86-88}$ and even between growth stages for many plants. ${ }^{89}$ Water limitation has an impact on plant growth, ${ }^{90}$ although the exact effect may vary depending on the intensity of the water stress imposed. ${ }^{91}$ A reduction in flower size is one of the consequences of exposing plants to water stress. ${ }^{91}$ Carroll et al. ${ }^{92}$ reported that drought led to a $33 \%$ decrease in flower size relative to controls. Reduction of flower size under drought stress was recorded in populations of Clarkia unguiculata distributed along a natural moisture gradient. ${ }^{93}$ The water stress, which decreased the water potential in the soil, reduced the flower head diameter. ${ }^{28}$ The effect on flower area as related to the decrease of water availability can be explained by the decrease in the influx from the vegetative portions of the plant to the reproductive organs ${ }^{83}$ and the biochemical limitation which prevails under drought stress. ${ }^{94,95}$

\section{Plant quality (attractiveness)}

Plant quality (attractiveness) varied significantly among species and water regimes. The interaction between species and water regimes was significant as well (Table 1). Plant quality decreased linearly with increasing drought in all species. Regressions were strongly linear with larger slopes for less tolerant species (Table 2). Increasing drought decreased the attractiveness of all Glaucium spp. to different degrees (Figure 7). Under the control treatment, there was no difference between G. flavum, and G. acutidentatum since both do equally well and achieved the maximum quality (10), while there was a slightly significant difference between G. grandiflorum (9.7) and G. corniculatum (9.5) (Figure 7). The treatment of 75\% ET did not have a significant effect on the quality of G. flavum or G. acutidentatum while it significantly reduced the quality of the other two species (Figure 7). All species were adversely affected at the water regimes of 50 and $25 \%$ ET, although G. flavum had less decline followed by G. acutidetutum, G. grandiflorum and G. corniculatum (Figure 7).

Plants express various responses to drought and develop a wide range of tolerance strategies that affect both morphological and physiological traits. ${ }^{96}$ These responses may be reflected in plant leaf greenness, leaf size, plant height and flowering quality. Water stress has been shown to significantly reduce plant size. ${ }^{97}$ Studies have also shown that drought stress can affect the growth of plant organs differently ${ }^{98}$ which may result in the alteration of morphology. ${ }^{99}$ Putievsky et al. ${ }^{100}$ reported that water stress had a negative impact on green tissue yield of geranium. Drought caused reduction in all growth parameters of Matricaria chamomile.$^{54}$ Furthermore, a study by Flexas and Medrano ${ }^{24}$ showed that moisture deficiency affects various physiological and metabolic responses such as stomatal closure, decline in growth rate and photosynthesis. Also, Baher et al. ${ }^{51}$ showed that greater soil water stress decreased plant height and total fresh and dry weight of Satureja hortensis. Colom and Vazzana ${ }^{52}$ showed that the number of branches per plant and total plant dry weight was negatively affected by water stress in Eragrostis curvula. The range of drought in which the plant is able to survive varies according to the species. ${ }^{101}$ The ability to limit $\mathrm{Na}+$ transport into the shoots, and to reduce the $\mathrm{Na}+$ accumulation in the rapidly growing shoot tissues, is critically important for maintenance of high growth rates and protection of the metabolic process in elongating cells from the toxic effects of $\mathrm{Na}^{54}$ which is a process that requires sufficient water in plant cells. The quality of lilies (plant height, flower bud length and flower diameter) decreased as water relations changed because of osmotic imbalances. ${ }^{73}$ Also, drought may directly or indirectly inhibit cell division and enlargement and finally the growth of the whole plant.

Some above ground visible morphological symptoms of plants are marginal yellowing/browning of foliage, premature fall of leaves, twig and branch die back, loss of vigor and stunted growth. Several previous studies have found similar results to our findings. Drought caused a decline in the quality of bermudagrass cultivars ${ }^{13}$ and seashore paspalum cultivars. ${ }^{102}$ In addition, elevated drought may adversely 
affect photosynthesis and as a result adversely affect plant biomass production through reduced accumulation of carbon products. ${ }^{78}$ The reduction in the number of flowers usually is more drastic than other growth parameters under high drought as it is a cumulative effect. ${ }^{54}$ Fewer flowers and reduced size of flowers adversely affect the attractiveness of landscape plants.

\section{Water use efficiency}

Drought avoidance is an important drought resistance strategy. Drought avoidance can be achieved through the reduction in water use or water loss through the canopy and increasing water uptake of roots from deeper soils. ET is a measure of water use efficiency and is an indicator of plant vigor. ET varied significantly $(\mathrm{P}<0.05)$ among species under different water regimes, among water regimes and their interaction (Table 1), (Table 2) (Table 3). Regression analysis indicated a significant negative linear relationship between water regimes and ET rates (Table 3). ET rate declined with the reduction in irrigation water. The decline in ET rate under lower water regimes was more severe and more rapid (Table 3). G. flavum showed lower ET rates under all water regimes when compared to G. acutidentatum, G. grandiflorum and G. corniculatum. G. corniculatum had the highest ET rates at all water regimes (Figure 3). Transpiration efficiency (TE) has been identified as one of the important physiological traits for improving drought adaptation of plants. The variation in TE is associated with variation in photosynthetic capacity per unit leaf area because thicker leaves usually have a higher density of chlorophyll per unit leaf area and hence have a greater photosynthetic capacity when compared with thinner leaves. Leaf thickness may also affect plant quality. G. flavum showed greater TE since it was able to maintain its ET at lower rates while maintaining higher attractiveness when compared with $\mathrm{G}$ acutidentatum which was next in TE with G. grandiflorum and G. corniculatum which had the lowest TE (Table 3). Many species have shown considerable interspecific diversity for various environmental stresses, including drought. ${ }^{10,103} \mathrm{Kim}$ and Beard ${ }^{104}$ found that species/ cultivar differences in ET rates under non-limiting soil moisture conditions were associated with canopy resistance and total leaf area. High canopy resistance and/or a low leaf area resulted in lower ET. Arunyanark et al.$^{105}$ reported a reduction in transpiration rate because of drought while the transpiration efficiency, as indicated by total dry matter production, was increased in peanut (Arachis hypogaea L.).

\section{Osmotic adjustment}

Osmotic adjustment facilitates water uptake and limits water loss from cells. Thus, tissues may sustain metabolic and physiological functions under drought stress in addition to the stability of cell membrane. Tested osmotic adjustment parameters included shoot total nonstructural carbohydrates, total reducing sugar content and shoot proline content.

\section{Shoot total nonstructural carbohydrates and total reducing sugar content}

Shoot TNC varied significantly among species, water regimes and their interaction (Table 1). Increasing drought decreased shoot TNC of Glaucium spp. (Table 4). Regression analysis indicated a significant negative linear relationship between water regimes and TNC content (Table 4). In G. flavum, as water regimes increased from control to 75,50 and $25 \%$ of the total ET, average TNC decreased by 15.1, 30.3 and $48.0 \%$ while the average TNC decrease in G. acutidentatum shoots was $21.6,40.1$, and $53.7 \%$. The decrease in G. grandiflorum was $21.4,42.7$ and $54.8 \%$ while the decrease in G. corniculatum was $27.0,53.7$ and 59.4\%, respectively. A decline in TNC was most likely due to the decline in photosynthesis because of stomatal closure as a water saving mechanism. Shoot RSC varied significantly among species, water regimes and their interactions (Table 1). RSC response to different drought treatments followed a different trend than TNC (Table 5). Reducing sugars in plants mainly consists of glucose and fructose. ${ }^{101,102}$ While nonstructural carbohydrates are energy reserves in plants, soluble reducing sugars are thought to play an important role in drought, salinity and freezing tolerance as osmoregulators and as protectants as they prevent cell desiccation. ${ }^{106}$ Regression analysis indicated a significant positive association between drought and RSC content in all species at all water regimes (Table 5). As water regimes increased from control to 75,50 and $25 \% \mathrm{ET}$, average RSC increased by 40.7, 101.8 and $166.5 \%$ in G. flavum and by $17.4,40.0$ and $103.4 \%$ in G. acutidentatum. The increase was 122.2 , 39.6 , and $90.6 \%$ in G. grandiflorum and $4.4,26.5$, and $62.5 \%$ in G. corniculatum, respectively. Carbon reduction could be related to the drought resistance mechanisms that are energy dependent. The results suggested that carbohydrate availability was a limiting factor for shoot growth under high drought stress. Shahba ${ }^{13}$ found an increase in RSC and a decrease in TNC with drought increase in bermudagrass species (Tifgreen, Tifdwarf and Tifway) and seashore paspalum cultivars. ${ }^{12,13}$

Soluble carbohydrates may interact with membrane phospholipids and proteins to stabilize their structures and prevent desiccation under drought stress. ${ }^{106} \mathrm{TNC}$ serves as the resource for the increased RSC under drought conditions. The balance between carbohydrate production and consumption impacts the ability of plants to cope with stresses..$^{9,10-13}$

\section{Shoot proline content}

Shoot proline content varied significantly among species, water regimes and their interaction (Table 1). Increasing drought increased shoot proline content of Glaucium species. The increase in proline content was more obvious with increasing drought (Table 6). As water regimes decreased from control to 75,50 and $25 \%$ average proline content in shoots increased by 186,325 , and $472 \%$ in G. flavum, 163, 303 and $517 \%$ in G. acutidentatum, 160, 280 and $418 \%$ in G. grandiflorum and 80,190 , and $340 \%$ in G. corniculatum, respectively. Regression analysis indicated a significant positive association between drought and proline content in all species (Table 6). Although the role of proline accumulation in drought tolerance is well documented in this study, it has been questioned by others. ${ }^{19}$ Our results suggest a positive role for proline in Glaucium species drought tolerance. A positive effect of proline accumulation in drought tolerance was also reported in seashore paspalum cultivars. ${ }^{55}$ Accumulation of proline in plant tissues in response to drought stress has been attributed to enzyme stabilization and/or osmoregulation. ${ }^{15,16}$ It could act as a sink for carbon and nitrogen for stress recovery and may buffer cellular redox potential under drought stress. ${ }^{14}$ Maggio et al. ${ }^{107}$ suggested that proline may act as a signaling/regulatory molecule able to activate multiple responses that participate in the adaptation process to environmental stresses. Little is known of metabolic factors controlling root survival in drying soils and the proteins or genes associated with the accumulation of osmolytes. ${ }^{108}$ The accumulation of solutes in leaves, such as soluble sugars, inorganic ions, and proline has been associated with osmotic adjustment and increased drought 
tolerance in Kentucky bluegrass, ${ }^{109}$ tall fescue, ${ }^{110}$ perennial ryegrass, ${ }^{111}$ and zoysiagrass. ${ }^{112}$ Osmotic adjustment has also been observed in roots of crops which contribute to the maintenance of root turgor and elongation in dry soils. ${ }^{113}$ A positive correlation between the capacity of osmotic adjustment and recovery from prolonged drought has been reported in several species, where species with the greatest osmotic adjustment regrew faster after watering. ${ }^{114}$ Any cultural practice that promotes accumulation of osmotic solutes during drought stress should be helpful in landscape plants for rapid recovery from that stress. On the basis of best results relative to categories for leaf characteristics, plant height, flowering characteristics, overall

Table 3 Effect of different water regimes on daily ET ( $\left.\mathrm{mmd}^{-1}\right)$ of Glaucium spp. linear regression of different ET rates vs. water regimes of control (C), 75, 50, and $25 \%$ of the total evapotranspiration

\begin{tabular}{llllllll}
\hline \multirow{2}{*}{ Species } & \multicolumn{9}{l}{ ET rate $\left(\mathbf{m m d}^{-1}\right)$} & \multirow{2}{*}{ Regression } & \multirow{2}{*}{$\mathbf{R}^{2}$} \\
\cline { 2 - 5 } & \multicolumn{4}{l}{ Water regimes $(\%$ of total ET) } & & \\
\cline { 2 - 5 } & $\mathbf{C}$ & $\mathbf{7 5}$ & $\mathbf{5 0}$ & $\mathbf{2 5}$ & & \\
\hline G. acutidentatum & $4.0 \mathrm{c} \dagger$ & $3.4 \mathrm{c}$ & $2.4 \mathrm{c}$ & $1.7 \mathrm{c}$ & $\mathrm{Y}=22.0-0.9 \times$ & $0.79 * *$ \\
G. corniculatum & $5.2 \mathrm{a}$ & $4.5 \mathrm{a}$ & $3.0 \mathrm{a}$ & $2.5 \mathrm{a}$ & $\mathrm{Y}=12.6-1.2 \mathrm{X}$ & $0.64 *$ \\
G. flavum & $4.0 \mathrm{c}$ & $3.3 \mathrm{c}$ & $2.2 \mathrm{c}$ & $1.2 \mathrm{~d}$ & $\mathrm{Y}=11.8-1.6 \mathrm{X}$ & $0.80^{* *}$ \\
G. grandiflorum & $4.4 \mathrm{~b}$ & $3.9 \mathrm{~b}$ & $2.7 \mathrm{~b}$ & $2.2 \mathrm{~b}$ & $\mathrm{Y}=10.7-0.8 \mathrm{X}$ & $0.72^{*}$ \\
\hline
\end{tabular}

†Values followed by the same letters within a column for each cultivar are not significantly different $(P=0.05)$ based on a Fisher's LSD test.

*Significant at P0.05.

**Significant at P0.0I.

Table 4 Total nonstructural carbohydrates (TNC) in shoots of Glaucium spp. measured at the end of the experiment vs. water regimes of control (C), 75,50 , and $25 \%$ ET

\begin{tabular}{|c|c|c|c|c|c|c|}
\hline \multirow{3}{*}{ Species } & \multicolumn{4}{|c|}{ TNC (mgg-1 dry wt) } & \multirow{3}{*}{ Regression } & \multirow{3}{*}{$\mathbf{R}^{2}$} \\
\hline & \multicolumn{4}{|c|}{ Water regimes (\%) } & & \\
\hline & C & 75 & 50 & 25 & & \\
\hline G. acutidentatum & $120.5 \mathrm{~b} \dagger$ & $94.5 b$ & $72.2 b$ & $55.8 \mathrm{~b}$ & $Y=\mid 22.5-2.1 X$ & $0.82 * *$ \\
\hline G. corniculatum & $98.3 d$ & $71.8 \mathrm{~d}$ & $45.5 d$ & $39.9 d$ & $Y=108.6-2.0 X$ & $0.79 *$ \\
\hline G. flavum & $126.6 \mathrm{a}$ & $107.5 \mathrm{a}$ & $88.2 a$ & $65.8 \mathrm{a}$ & $Y=107.2-1.9 X$ & $0.86 * *$ \\
\hline G. grandiflorum & $103.8 c$ & $81.6 c$ & $59.5 c$ & $46.9 c$ & $Y=1 \mid 5.3-1.8 X$ & $0.76 *$ \\
\hline
\end{tabular}

†Values followed by the same letters within a column for each cultivar are not significantly different $(P=0.05)$ based on a Fisher's LSD test.

*Significant at P0.05.

**Significant at P0.0I.

Table 5 Total reducing sugar content (RSC) in shoots of Glaucium spp. measured at the end of the experiment vs. water regimes of control (C), 75,50 , and $25 \%$ ET

\begin{tabular}{|c|c|c|c|c|c|c|}
\hline \multirow{3}{*}{ Species } & \multicolumn{4}{|c|}{ 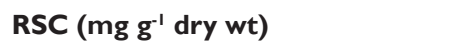 } & \multirow{3}{*}{ Regression } & \multirow{3}{*}{$\mathbf{R}^{2}$} \\
\hline & \multicolumn{4}{|c|}{ Water regimes (\%) } & & \\
\hline & C & 75 & 50 & 25 & & \\
\hline G. acutidentatum & 17.8 & $20.9 \mathrm{~b} t$ & $24.2 b$ & $36.2 b$ & $Y=20.5+0.14 X$ & $0.78 * *$ \\
\hline G. corniculatum & 13.6 & $\mathrm{I} 4.2 \mathrm{~d}$ & $17.2 \mathrm{~d}$ & $22.1 d$ & $Y=15.2+0.13 X$ & $0.70 *$ \\
\hline G. flavum & 16.7 & $23.5 \mathrm{a}$ & $33.7 \mathrm{a}$ & $44.5 \mathrm{a}$ & $Y=10.9+0.25 X$ & $0.88 * *$ \\
\hline G. grandiflorum & 14.9 & $18.2 \mathrm{c}$ & $20.8 \mathrm{cb}$ & $28.4 c$ & $Y=14.5+0.14 X$ & $0.75 *$ \\
\hline
\end{tabular}

†Values followed by the same letters within a column for each cultivar are not significantly different $(P=0.05)$ based on a Fisher's LSD test.

*Significant at P0.05

**Significant at $\mathrm{P} \leq 0.0 \mathrm{I}$.

Citation: Getlawi AO, Shahba MA, Hughes HG. Screening glaucium species for drought resistance with emphasis on the contributing physiological characters and overall performance. Horticult Int J. 20I9;3(2):I00-II3. DOI: I0.15406/hij.2019.03.00II7 
Table 6 Proline content in shoots of Glaucium spp. measured at the end of the experiment vs. water regimes of control (C), 75,50 , and $25 \%$ ET

\begin{tabular}{|c|c|c|c|c|c|c|}
\hline \multirow{3}{*}{ Species } & \multicolumn{4}{|c|}{ Proline content ( $\mu \mathrm{g} \mathrm{g}^{-1}$ fresh $\left.\mathrm{wt}\right)$} & \multirow{3}{*}{ Regression } & \multirow{3}{*}{$\mathbf{R}^{2}$} \\
\hline & \multicolumn{4}{|c|}{ Water regimes (\%) } & & \\
\hline & C & 75 & 50 & 25 & & \\
\hline G. acutidentatum & 243.0 & $639.0 \mathrm{bt}$ & $980.0 \mathrm{~b}$ & $1499.0 \mathrm{~b}$ & $Y=218.3+22.9 X$ & $0.82 * *$ \\
\hline G. corniculatum & 226.9 & $408.0 d$ & $659.0 \mathrm{~d}$ & $998.0 \mathrm{~d}$ & $Y=|44.5+| 4.5 X$ & $0.72 *$ \\
\hline G. flavum & 281.5 & $805.0 \mathrm{a}$ & II95.0a & $1610.0 \mathrm{a}$ & $Y=|39.6+| 1.4 X$ & $0.90 * *$ \\
\hline G. grandiflorum & 223.2 & $580.0 c$ & $849.0 c$ & $1155.0 \mathrm{c}$ & $Y=172.2+18.4 X$ & $0.74 *$ \\
\hline
\end{tabular}

†Values followed by the same letters within a column for each cultivar are not significantly different $(P=0.05)$ based on a Fisher's LSD test. *Significant at P0.05.

$* *$ Significant at $\mathrm{P} \leq 0.0 \mathrm{I}$

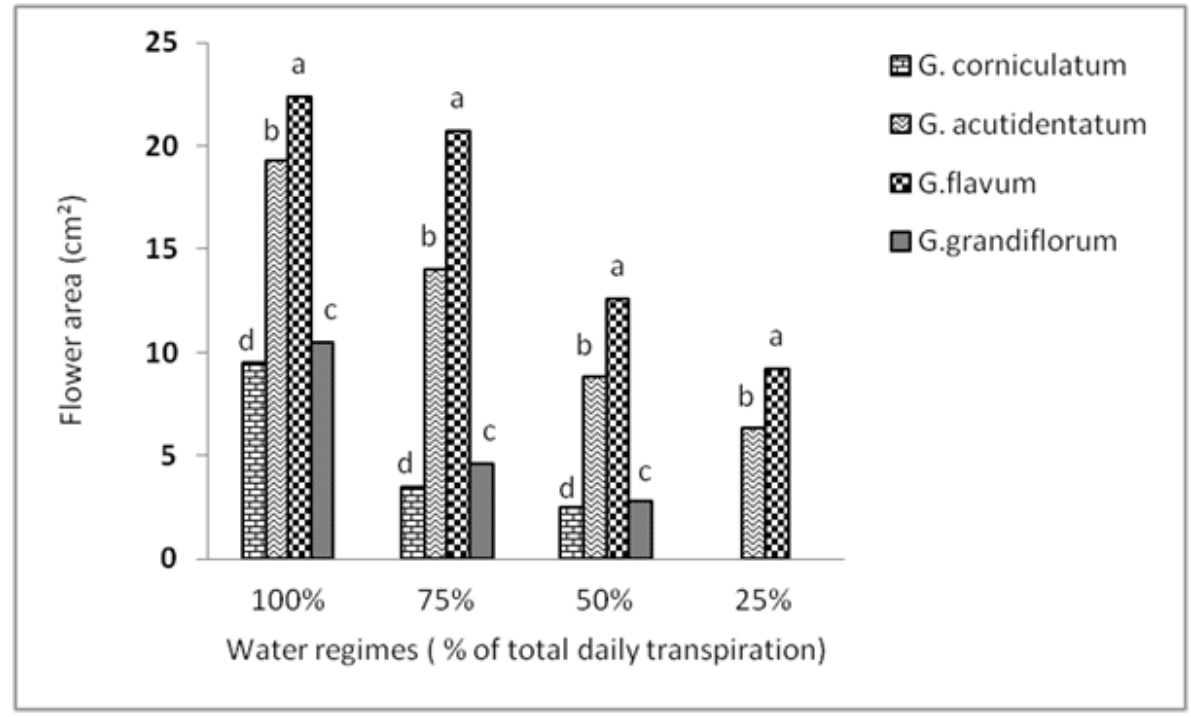

Figure 6 Effect of four different water regimes on flower area of four Glaucium spp. Columns labeled with different letters are significantly different at $\mathrm{P}=0.05$ within each water regime.

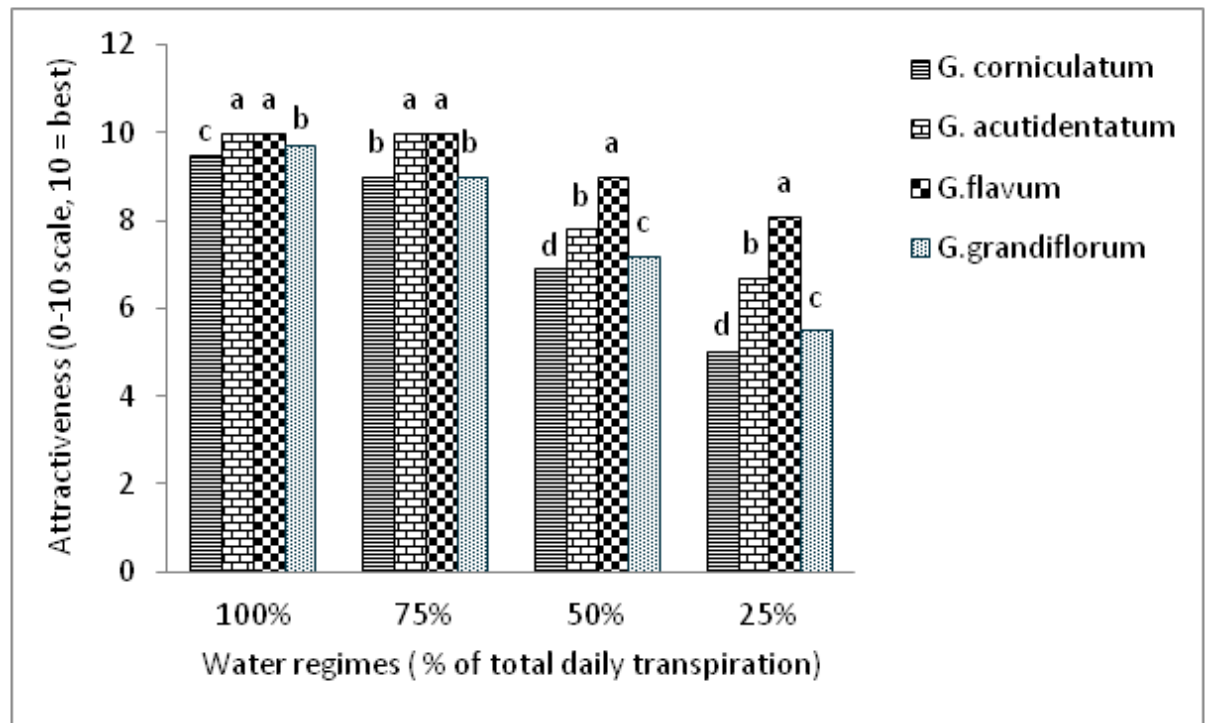

Figure 7 Effect of four different water regimes on the attractiveness of four Glaucium spp. Columns labeled with different letters are significantly different at $\mathrm{P}=0.05$ within each water regime. 


\section{Acknowledgments}

None.

\section{Conflicts of interest}

Authors declare that there is no conflict of interest.

\section{References}

1. Soeder, DJ, Kappel WM. Water resources and natural gas production from the Marcellus shale. Reston, Virginia: US Department of the Interior, US Geological Survey. 2009.

2. Duncan RR, RN Carrow. Turfgrass molecular genetic improvement for biotic/edaphic stress resistance. Adv Agron. 1999;67:233-305.

3. Igartua E. Choice of selection environment for improving crop yields in saline areas. Theor Appl Genet. 1995;91(6-7):1016-1021.

4. Maas EV, Hoffman GJ. Crop salt tolerance: current assessment Journal of the Irrigation and Drainage Division. Am Soc Civil Eng. 1977;103(IR2):116-134.

5. Grey-Wilson C. Poppies: A guide to the poppy family in the wild and in cultivation. Timber Press, Portland; 2000.

6. Davis PH. Flora of turkey and east aegean islands. Edinburgh University, Edinburg; 1965-1985;1-9.

7. Beard JB. Turfgrass water stress: Drought tolerance components physiological mechanisms, and species-genotype diversity. In: H Takatoh, editor, Jpn Soc Turf Sci. Tokyo. 1989;23-28.

8. Turner NC. Crop water deficits: a decade of progress. Adv Agron 1986;39:1-51.

9. Huang B, J Fry. Turfgrass evapotranspiration. Water Use in Crop Production. In: MB Kirkham, editor, Food Products Press. New York; 1999;317-334

10. Lee GJ, RN Carrow, RR Duncan. Identification of new soluble sugars accumulated in a halophytic seashore paspalum ecotype under salinity stress. Hort Environ Biotechnol. 2008a;49(1):13-19.

11. Lee GJ, RN Carrow, RR Duncan, et al. Synthesis of organic osmolytes and salt tolerance mechanisms in Paspalum vaginatum. Env Exp Bot. 2008b;63(1-3):19-27.

12. Shahba MA. Interaction effects of salinity and mowing on performance and physiology of bermudagrass cultivars. Crop Sci. 2010b;50:2620 2631.

13. Shahba MA, SF Alshammary, MS Abbas. Effects of salinity on seashore paspalum cultivars at different mowing heights. Crop Sci. 2012;52:13581370.

14. Ashraf M, MR Foolad. Role of glycine betaine and proline in improving plant abiotic stress resistance. Environmental and Experimental Botany. 2007;59:206-216.

15. Flowers TJ, PF Troke, AR Yeo. The mechanism of salt tolerance in halophytes. Annu Rev Plant Physiol. 1977;28:89-121.

16. Levitt J. Salt stresses. In: Responses of plants to environmental stresses. Academic Press. 1980;(2):365-454.

17. Marcum KB. Growth and physiological adaptations of grasses to salinity stress. In: Pessarakli M, editors, Handbook of Plant and Crop Physiology, 2nd ed. Marcel Dekker, New York; 2002.

18. Torello WA, LA Rice. Effects of $\mathrm{NaCl}$ stress on proline and cation accumulation in salt sensitive and tolerant turfgrasses. Plant and Soil. 1986;93:241-247.
19. Ashraf M, PJC Harris. Potential biochemical indicators of salinity tolerance in plants. Plant Science. 2004;166:3-16.

20. Chatterton NJ, JH Bennett, WR Thornley. Fructan, starch, and sucrose concentrations in crested wheatgrass and redtop as affected by temperature. Plant Physiol and Biochem. 1987;25:617-623.

21. Bates LS, RP Waldren, ID Teare. Rapid determination of free proline for water stress studies. Plant and Soil. 1973;39:205-207.

22. SAS Institute. SAS/STAT user's guide. SAS Institute, Cary. NC. 2006.

23. Yadollahi A, Arzani K, Ebadi A, et al. The response of different almond genotypes to moderate and severe water stress in order to screen for drought tolerance. Scientia Horticulturae. 2011;129:403-413.

24. Flexas J, H Medrano. Drought-inhibition of photosynthesis in C3 plants stomatal and non-stomatal limitations revisited. Ann Bot. 2002;89:183189.

25. Lenis JI, Calle F, Jaramillo G, et al. Leaf retention and cassava productivity. Field Crops Research. 2006;95:126-134

26. Gibon YR, Sulpice, F Larher. Proline accumulation in canola leaf discs subjected to osmotic stress is related to the loss of chlorophylls and to the decrease of mitochondrial activity. Physiol Plant. 2000;4:469-476.

27. Din J, SU Khan, I Ali, et al. Physiological and agronomic response of canola varieties to drought stress. J Anim Plant Sci. 21(1):78-82.

28. Liu D, Pei ZF, Naeem MS, et al. 5-Aminolevulinic acid activates antioxidative defence system and seedling growth in brassica napus 1. under water-deficit stress. Journal of Agronomy and Crop Science. 2011;197(4):284-295

29. Mihailovie N, Lazarevie M, Dzeletovie Z, et al. Chlorophyllase activity in wheat Triticum aestivum L. leaves during drought and its dependence on the nitrogen ion form applied. Plant Sci. 1997;129:141-146.

30. Lei Y, Yin C, Li C. Differences in some morphological, physiological, and biochemical responses to drought stress in two contrasting populations of Populus przewalskii. Physiol Plant. 2006;127:182-191.

31. Boyer JS. Leaf enlargement and metabolic rates in corn, soybean and sunflower at various leaf water potentials. Plant physiol. 1970;46:233235.

32. Gehrmann H. Growth, yield and fruit quality of strawberries as affected by water supply. Acta hort. 1985;171:463-469.

33. Singer SM, Helmy YI, Karas AN, et al. Influences of different water stress treatments on growth, development and production of snap bean (Phaseolus vulgaris L.). Acta hort. 2003;614:605-611.

34. Lecoeur J, Wery J, Turc O, et al. Expansion of pea leaves subjected to short water deficit: cell number and cell size are sensitive to stress a different periods of leaf development. J Exp Bot. 1995;46:1093-1101.

35. Lecoeur J, Guilioni L. Rate of leaf production in response to soil water deficits in field pea. Field crops research. 1998;57(3), 319-328.

36. Hessini K, Juan Pablo Martínez, Mhemmed Gandour, et al. Effect of water stress on growth, osmotic adjustment, cell wall elasticity and mwateruse efficiency in Spartina alterniflora. Environmental and Experimental Botany. 2009;67:312-319.

37. Grant OM, Johnson AW, Davies MJ, et al. Physiological and morphological diversity of cultivated strawberry Fragaria $\mathrm{X}$ ananassa) in response to water deficit. Environmental and Experimental Botany. 2010;68(3):264-272

38. Klamkowski K, W Treder. Response to drought stress of three strawberry cultivars grown under greenhouse conditions. J Fruit Ornam Plant Res. 2008;16:179-188. 
39. Madramootoo CA, Rigby M. Effects of trickle irrigation on the growth and sunscald of bell peppers (Capsicum annuum L.) in southern Quebec. Agric Water Manage. 1991;19:181-189.

40. Tahar Boutraa, Abdellah Akhkha, Abdulkhaliq A. et al. Effect of water stress on growth and water use efficiency (WUE) of some wheat cultivars (Triticum durum) grown in Saudi Arabia. JTUSCI. 2010;3:39-48.

41. Kameli BA, DM Losel. Growth and sugar accumulation in durum whea plants under water stress. New Phytol. 1996;132:57-62.

42. Kirnak H, Tas I, Kaya C, et al. Effects of deficit irrigation on growth, yield, and fruit quality of eggplant under semi-arid conditions. Aust $J$ Agric Res. 2002;53:1367-1373.

43. Alexieva V, I Sergiev, S Mapelli, et al. The effect of drought and ultraviolet radiation on growth and stress markers in pea and wheat. Plant Cell and Environment. 2001;24:1337-1344.

44. Marcelis LFM, Heuvelink E, Goudriaan J. Modelling biomass production and yield of horticultural crops: a review. Sci Hortic. 1998;74:83-111.

45. Jensen CR, Mogensen VO, Mortensen G, et al. Seed glucosinolate, oil and protein contents of field-grown rape (Brassica napus L.) affected by soil drying and evaporative demand. Field Crops Research. 1996;47(3):93105.

46. Tardieu F, Granier C, Muller B. Modelling leaf expansion in a fluctuating environment: are changes in specific leaf area a consequence of changes in expansion rate?. New Phytol. 1999;143:33-43.

47. Wright GC, Rao RCN, Farquhar GD. Water-use efficiency and carbon isotope discrimination in peanuts under water deficit conditions. Crop Sci. 1994;34:92-97.

48. Craufurd PQ, Wheeler TR, Ellis RH, et al. Effect of temperature and water deficit on water-use efficiency, carbon isotope discrimination, and specific leaf area in peanut. Crop Sci. 1999;39(1):136-142.

49. Passioura JB. Environmental biology and crop improvement. Funct Plant Biol. 2002;29:537-546.

50. Schuppler U, He PH, John PCL, et al. Effect of water stress on cell division and cell-division-cycle 2-like cell cycle kinase activity in wheat leaves. Plant Physiology. 1998;117:667-678.

51. Baher, Z.F., M. Mirza, M. Ghorbanli, et al. The influence of water stress on plant height, herbal and essential oil yield and composition in Satureja hortansis L. Flavour Frag J. 2002;17:275-277.

52. Colom MR, C Vazzana. Water stress effects on three cultivars of Eragrostis curvula. Italy J Agron. 2002;6:127-132.

53. Lin L, Wenwen Li, Jingqing Shao, et al. Modelling the effects of soil water potential on growth and quality of cut chrysanthemum (Chrysanthemum morifolium). Scientia Horticulturae. 2011;130:275-288.

54. Razmjoo K. Parisa heydarizadeh, Mohammad RS. Effect of drough and drought stresses on growth parametersm and essential oil content of matricaria chamomile. Int J Agri Biol. 2008;10(4):451-454.

55. Shia Uddin, Shahnaj Parvin, MA Awal. Morpo- aspets of mungbean (Vigna Radiata L.) In Response To Water Stress. IJASR. 2013;3:137-148.

56. Greenway H, R Munns. Mechanisms of salt tolerance in non-halophytes. Annu Rev Plant Physiol. 1980;31:149-190.

57. Dumbroff EB, A Cooper. Effects of salt stress applied in balanced nutrient solutions at several stages during growth of tomato. Bot Gaz. $1974 ; 135: 219-224$

58. Chartzoulakis K, G Klapaki. Response of two greenhouse pepper hybrid to $\mathrm{NaCl}$ salinity during different growth stages. Scientia Horticulturae. 2000;86(3):247-260.
59. Marcum KB. Salinity tolerance in turfgrasses.. In: M Pessarakli, editor, Handbook of plant and crop stress. Marcel Dekker, New York; 1999:891905

60. Dudeck AE, S Singh, CE Giordano, et al. Effects of sodium chloride on cynodon turfgrasses. Agron J. 1983;75:927-930.

61. Peacock $\mathrm{CH}, \mathrm{AE}$ Dudeck. Physiological and growth responses of seashore paspalum to salinity. HortScience. 1985;20:111-112.

62. Ranawake AL, Dahanayaka N, Amarasingha UGS, et al. Effect of water stress on growth and yield of mung bean (Vigna radiate L.). Journal of Tropical Agricultural Research \& Extension. 2011;14:1-4

63. Rozema J, M Visser. The applicability of the rooting technique measuring salt resistance in populations of Festuca rubra and Juncus species. Plan Soil. 1981;62:479-485.

64. Sheoran IS, HS Saini. Drought-induced male sterility in rice: changes in carbohydrate levels and enzyme activities associated with the inhibition of starch accumulation in pollen. Sex Plant Reprod. 1996;9:161-169.

65. KoshitaY, T Takahara. Effect of water stress on flower-bud formation and plant hormone content of satsuma mandarin (Citrus unshiu Marc.) Scientia Horticulturae. 2004;99:301-307.

66. Southwick SM, Davenport TL. Characterization of water stress and low temperature effects on flower induction in citrus. Plant Physiol. $1986 ; 81: 26-29$

67. Katayama H, Okada N, Yamazaki T, et al. The influence of mulching with film of vacuum evaporation by Al from June to November on tree constituents and fruit qualities in satsuma mandarin. J Jpn Soc Hort Sci. 1989;58(Suppl. 2):96-97.

68. Istanbulluoglu A, B Arslan, E Gocmen, et al. Effects of deficit irrigation regimes on the yield and growth of oilseed rape (Brassica napus L.). Biosystems Engineering. 2010;105:388-394.

69. Loka DA. DM Oosterhuis. Effect of water-deficit stress on reproductive development in the cotton pistil. Summaries of Arkansas Cotton Research 2009;37-54.

70. Hirose K. Control of citrus flower bud formation. I. The effect of gibberellic acid spraying on flower bud formation in satsuma orange. Bill Hort Res Sta. 1968;B8:1-11.

71. Munns R. Comparative physiology of salt and water stress. Plant Cell Environ. 2003;25(2):239-250.

72. Cheeseman JM. Mechanisms of salinity tolerance in plants. Plant Physiol. 1988;87:745-755.

73. Küçükahmetler O. The effects of salinity on yield and quality of ornamenta plants and cut flowers. Acta Horticulturae (ISHS). 2002;573:407-414.

74. Fu JM, AJ Koski, YL Qian. Responses of creeping bentgrass to salinity and mowing management: growth and turf quality. Hort Science. 2005;40(2):463-467.

75. Flowers T, E Duque, MA Hajibagheri, et al. The eff ect of salinity on leaf ultrastructure and net photosynthesis of two varieties of rice: Further evidence for a cellular component of salt-resistance. New Phytol. $1985 ; 100: 37-43$

76. Lee GJ, RN Carrow, RR Duncan. Photosynthetic responses to salinity stress in halophytic seashore paspalum genotypes. Plant Sci. 2004C;166:1417-1425

77. Pessarakli M, H Touchane. Growth responses of bermudagrass and seashore paspalum under various levels of sodium chloride stress. J Food Agric Environ. 2006;4:240-243.

78. Munns R, A Termatt. Whole-plant responses to salinity. Aust J Plant Physiol. 1986;13:143-160. 
79. Saxena MC, Hawtin GC, El-Ibrahim H. Aspects of faba bean ideotypes for drier conditions. In: Thomson R, editor, Vicia faba: Physiology and Breeding. Martinus Nijhoff. 1981;210-231.

80. Zinselmeier C, Lauer MJ, Boyer JS. Reversing drought induced losses in grain-yield; sucrose maintains embryo growth in maize. Crop Sci. $1995 ; 35: 1390-1400$

81. Samarah NH, Alqudah A, Amayreh J, et al. The effect of late-terminal drought stress on yield components of four barley cultivars. J Agron Crop Sci. 2009a; 195:427-441

82. Samarah NH, Haddad N, Alqudah A.Yield potential evaluation in chickpea genotypes under late terminal drought in relation to the length of reproductive stage. Italian J Agron. (2009b);3:111-117.

83. Mohan Ram HY, Rao IV. Physiology of flower bud growth and opening Proc Indian Acad Natural Sci. 1984;93:253-274.

84. Wopereis MCS, Ropff M, Maligaya A, et al. Drought-stress responses of two lowland rice cultivars to soil water status. Field Crop Res. 1996;46(1-3):21-39.

85. Winkel T, Renno JF, Payne WA. Effect of the timing of water deficit on growth, phenology and yield of pearl millet (Pennisetum glaucum (L.) Grown in Sahelian conditions. J Exp Bot. 1997;48:1001-1009.

86. Zollinger N, Kjelgren R, Cerny-Koenig T, et al. Drought responses of six ornamental herbaceous perennials. Sci Hort. 2006;109 (3):267-274.

87. Clary J, Save'R, Biel C, et al. Water relations in competitive interactions of Mediterranean grasses and shrubs. Ann Appl Biol. 2004;144:149-155.

88. Save R, Biel C, De Herralde F. Leaf pubescence, water relations and chlorophyll fluorescence in two subspecies of lotus creticus $L$ Biol Plant. 2000;43:239-244.

89. Sionit N, Patterson DT, Coffin D, et al. Water relations and growth of the wees, goosegrass (Eleusine indica), under drought stress. Field Crops Res. 1987; 17:163-173.

90. Franco JA, Martinez-Sanchez JJ, Fernandez JA, et al. Selection and nursery production of ornamental plants for landscaping and xerogardening in semi-arid environments. J Hort Sci Biotechnol. 2006;81:3-17.

91. Cameron RWF, Harrison-Murray RS, Scott MA, et al. The use of controlled water stress to manipulate growth of container-grown Rhododendron cv. Hoppy. J Hort Sci Biotechnol. 1999;74:161-169.

92. Carroll AB, SG Pallardy, C Galen. Drought stress, plant water status, and floral trait expression in fireweed, epilobium angustifolium (Onagraceae). American Journal of Botany. 2001;88(3):438-446.

93. Jonas CS, MA Geber. Variation among populations of Clarkia unguiculata (Onagraceae) along altitudinal and latitudinal gradients. American Journal of Botany. 1999;86(3):333-343.

94. Jones HG. Plants and microclimate: a quantitative approach to environmental plant physiology. Cambridge University Press. 1992.

95. Cornic G, Massacci A. Leaf photosynthesis under drought stress. In Baker NR, editor, Photosynthesis and the Environment. Kluwer Academic Publishers. The Netherlands. 1996;347-366.

96. Blum A. Crop response to drought and the interpretation of adaptation Plant Growth Regul. 1996;20:135-148.

97. Champolivier LA, Merrien. Effects of water stress applied at differen growth stages to Brassica napus L. var. oleifera on yield, yield components and seed quality. European Journal of Agronomy. 1996;5:153-160.
98. SpollenWG. Sharp RE, Saab IN. Regulation of cell expansion in roots and shoots at low water potentials. In: Smith JAC, Griffiths H, editors, Water Deficits: Plant Responses from Cell to Community. Oxford, 1993;37-52.

99. French RJ, Turner NC. Water deficit change dry matter partitioning and seed yield in narrow-leafed lupins (Lupinus angustifolius L.). Aust $J$ Agric Res. 1991;42:471-484.

100. Putievsky E, U Ravid, N Dudai. The effect of water stress on yield components and essential oils of Pelargonium graveolens L. J Essen Oil Res. 1990;2(3):111-114.

101. Ball MC. Salinity tolerance in the mangroves Aegiceras corniculatum and Avicennia marina. I. Water use in relation to growth, carbon partitioning, and salt balance. Aust J Plant Physiol. 1988;15:447-464.

102. Shahba MA, YL Qian, HG Hughes, et al. Relationship of carbohydrates and cold hardiness in six saltgrass accessions. Crop Sci. 2003;43:21482153.

103. Trenholm, LE, RR Duncan, RN Carrow. Wear tolerance, shoot performance, and spectral reflectance of seashore paspalum and bermudagrass. Crop Sci. 1999;39:1147-1152.

104. Kim KS, JB Beard. Comparative turfgrass evapotranspiration rates and associated plant morphological characteristics. Crop Sci. 1988;28:328331.

105. Arunyanark A, S Jogloy, C Akkasaeng, et al. Chlorophyll stability is an indicator of drought tolerance in peanut. Journal of Agronomy and Crop Science. 2008;194(2):113-125.

106. Popp M, N Smirnoff. Polyol accumulation and metabolism during water deficit. In: N Smirnoff, editor, Environment and plant metabolism. Flexibility and acclimation. Bios Scientific, Oxford. 1995;199-215.

107. Maggio AS, Miyazaki P, Veronese T, et al. Does proline accumulation play an active role in stress induced growth reduction? Plant J. 2002;31:699712 .

108. Huang B. Mechanisms and Strategies for improving drought resistance in turfgrass. Acta Hort. 2008;783:221-227.

109. Jiang Y, B Huang. Drought and heat stress injury to two cool-season turfgrasses in relation to antioxidant metabolism and lipid peroxidation. Crop Sci. 2001;41:436-442.

110. Richardson MD, GW Chapman, CS Hoveland, et al. Sugar alcohols in endophyte-infected tall fescue under drought. Crop Sci. 1992;32:10601061.

111. Thomas H. Osmotic adjustment in Lolium perenne; tts heritability and the nature of solute accumulation. Ann Bot. 1990;66:521-530.

112. Qian YL, JD Fry, WS Upham. Rooting and drought avoidance of warmseason turfgrasses and tall fescue in Kansas. Crop Sci. 1997;37:905-910.

113. Sharp RE, TC Hsiao, WK Silk. Growth of the maize primary root at low water potentials II. Role of growth and deposition of hexose and potassium in osmotic adjustment. Plant Physiol. 1990;93:1337-1346.

114. DaCosta M, B Huang. Minimum water requirements for creeping, colonial and velvet bentgrasses under fairway conditions. Crop Sci. 2006;46:81-89. 